\title{
How Small Enterprises in Ghana Have Responded to Adjustment
}

\author{
William F. Steel and Leila M. Webster
}

\begin{abstract}
Monitoring of adjustment has focused on larger, often state-owned enterprises, many of which have been adversely affected by the more competitive environment. Little is known, however, about the impact of adjustment policies on small firms. Firm-level data from Ghana show that the adjustment process was well under way across sectors and within firms and that new investment was taking place. The adjustment process had strained most firms' operations-profits were squeezed between rising input costs and weak domestic demand and low-cost competing imports. Small-scale industries were forced to become more competitive to survive. Interviews with owners of small firms revealed considerable entrepreneurial initiative in changing product mix and seeking newly opened market niches. Sample entrepreneurs fell into two broad groups: dynamic, successful adapters with good prospects (found mostly among small-scale enterprises) and stagnant producers who had not adapted to the new competitive environment (found mostly among microenterprises). For potentially dynamic small firms, the most critical constraint was lack of access to finance for working capital and new investment. Many microentrepreneurs were seriously constrained by a lack of purchasing power among the lower-income population and by saturation of the sector.
\end{abstract}

This article uses a survey of 82 manufacturing firms in Ghana to analyze how small, private enterprises responded to structural adjustment reforms and how their contribution to economic growth could be enhanced. Growth of private indigenous enterprises is important for sustained industrial development, given decreasing public ownership and uncertain prospects for foreign investment. But the absence of data on small firms, where most Ghanaian entrepreneurs are found, makes it difficult to assess their prospects in the changed environment. The survey reported here represents a rapid assessment technique for analyzing how different types of firms respond to adjustment policies and what constraints need to be addressed for them to realize their potential.

William F. Steel and Leila M. Webster are with the Industry and Energy Department of the World Bank. The data were gathered with the assistance of the Ghana National Board for Small-Scale Industries. The authors are grateful to E. K. Abaka, Frederick Gyebi Acquaye, and John Wayem for assistance and to Kwamena Adjaye, Surendra Agarwal, Benson Ateng, Nancy Barry, Stephanie Gerard, Don Mead, and two anonymous referees for their comments.

(C) 1992 The International Bank for Reconstruction and Development/THE WORLD BANK 
Gharra introduced an Economic Recovery Program (ERP) in 1983 to redress some of the causes of its long economic decline. The ERP's key elements had different implications for different types of industry. Supported by adjustment lending, import liberalization increased access to previously restricted inputs and spare parts (especially for small firms), but also broadened competition from imported products. Massive realignment of the highly overvalued exchange rate created new opportunities for export and import substitution, but adversely affected import-dependent industries by sharply raising the price of imported inputs and the cost of financing them. In principle, price liberalization permitted firms to pass through higher costs, but in practice many could not because demand was restrained by stabilization measures and competition was high, especially in self-employment activities with low barriers to entry.

The study focuses on small-scale enterprises (SSES) for two principal reasons. The first reason is to investigate the view that African countries lack the dynamic entrepreneurs needed to initiate and sustain the process of industrialization. In this sense, SSEs-defined for this study as having from 4 to 29 full-time workers-can be distinguished from microenterprises with fewer than 4 workers, which are more likely to be informal and oriented toward income for survival. In Ghana SSEs had been discouraged by excessive regulation, distorted incentives, and state domination of industry. Hence we hypothesized that liberalization of markets would enable potential industrialists to emerge.

The second reason for our focus on SSEs is to assess the extent to which flexible organization and technology and relatively high labor intensity enable SSES to survive during adjustment. We hypothesized that SSES would be better able than large firms to respond quickly to the dramatic changes under Ghana's ERP and that smaller firms might absorb the surplus labor being shed by larger ones.

A consensus emerging from the literature is that the fundamental issue is how to create a policy and business environment that enables SSEs to contribute productively to industrial development, not whether SSES have a role to play (Liedholm 1990; Schmitz 1982). Hence the study examines constraints on firms' ability to respond to changing incentives and how these differ by firm size. In particular, we hypothesized that microenterprises-defined in the Ghanaian context as having fewer than 4 full-time workers (including self-employment)would serve more as a safety valve for surplus labor and be less able to respond to the ERP, given their low barriers to entry and limited access to resources.

The data were collected through interviews lasting one to two hours during three weeks in November 1989. The survey was conducted in two major urban centers, one medium-size town, and two rural towns to represent a cross-section of urban/rural and growing/stable settings. An effort was made to represent the range of activities in which SSES are typically found, although the lack of suitable census data made it difficult to select a statistically representative sample. Sixtysix ( 80 percent) of the 82 firms surveyed fell into six subsectors that accounted for 81 percent of employment recorded in the industrial census (Ghana 1989) 
and 86 percent of total manufacturing employment in the population census (Ghana 1987): food processing, textiles and garments, wood products, soap and cosmetics, metal products, and building materials. The oldest firm started in 1950 and the most recent in 1989. Forty-eight firms (59 percent) started before 1984, and 33 (40 percent) began operations between 1984 and 1989. These data were supplemented by an additional survey of selected questions for large firms with 30 or more workers.

The analysis focuses on differences across firm size categories, which generally yielded the most interesting results. Selected firm characteristics such as subsector and age are also analyzed. Firm characteristics are to some extent interrelated: no firms established since 1986 were large, and microenterprises were slightly overrepresented in the food and metal subsectors, as were SSES in wood products. The small number of observations, however, precluded statistically disentangling the separate effects of different variables. The aim, rather, was to arrive at indicative answers to the research hypotheses.

Preceding the analysis of survey findings, section I summarizes the literature on the role of sSEs in industrial adjustment, and section II reviews the preadjustment context. Section III characterizes the entrepreneurs in the sample, and section IV examines changes in employment, output, and investment under the adjustment program. Sections V and VI analyze adaptive response and constraints on adjustment, and section VII presents the conclusions.

\section{The Role of Small Enterprises in African Indust rial Adjustment}

In the period after independence, many African countries attempted to leap directly to a modern industrial structure through public investment in large-scale industries. The state often took the lead for lack of a strong indigenous entrepreneurial class and to avoid dependence on foreign investors. But inadequate attention to economic viability and market prospects resulted in substantial excess capacity, with many large firms unable to survive without heavy protection or subsidies. Many enterprises were squeezed, first, by economic crisis and, subsequently, by adjustment policies that reduced protection, cut back subsidies, restrained demand, and changed relative prices. Given budgetary restraints and a policy shift away from direct ownership of productive enterprises, governments have had to look increasingly to the private sector to take the lead in future industrialization.

Both cross-sectional and time-series data suggest that the industrialization process normally involves initial rapid growth of production in small-scale enterprises, some of which may expand into medium- and large-scale firms or survive in market niches even as large-scale industries gradually come to dominate the size distribution (Anderson 1982; Cortes and others 1987; Liedholm and Mead 1987; Little and others 1987; Nanjundan 1987; Staley and Morse 1965). In most African countries, the bulk of manufacturing employment is in self-employment and enterprises of fewer than 10 workers, while most output is 
generally produced in large firms of more than 100 workers (Liedholm and Mead 1987). Thus, some observers argue that there is a "missing middle" in the size distribution of industry in African countries that must be filled for private initiative to sustain industrial development (Kilby 1988).

We follow much of the literature in distinguishing SSEs from household and cottage industries that are essentially self-employment with low barriers to entry. SSEs may be defined as production units with hired labor that involve enough investment in capital or skills to constitute a barrier to entry but are small enough to be managed by one person. Few of the firms surveyed were part of an informal sector in the sense of being outside the legal framework. Although many of the smaller firms appeared "informal" in the organization of their production process, all but a few were registered as businesses and paid taxes at least to the local district. Many gradations of "formality" in different aspects of business operation were observed. Hence we have avoided the term "informal sector" and instead have used size categories that can be objectively measured. The number of workers is a measurable and therefore convenient indicator of size, although it must be recognized that dividing lines between groups are arbitrary.

The following arguments have been used to justify the expansion of SSEs as a desirable strategy.

- Successful industrialization must have an indigenous base, and expansion of the SSE sector would help develop entrepreneurial and managerial skills as a basis for efficient indigenous investment in and management of larger industries (Bolton Committee 1971; Bruton 1990; Kilby 1988).

- Because sses tend to be relatively labor-intensive and to use low levels of technology, a strategy to expand the SSE sector is likely to be consistent with employment and income distribution objectives while allowing for sustained productivity increases through improvements in technology (Staley and Morse 1965; Steel and Takagi 1983).

- Abolishing restrictive licensing, tax incentives for large firms, and direct allocation of credit, materials, and foreign exchange to large firms (especially in the public sector) is likely to unleash investment by sSEs in previously untapped opportunities (Little and others 1987; UNIDO 1989).

- ssEs can respond flexibly under difficult and changing conditions because they do not depend heavily on infrastructure and because their typically low levels of technology allow product lines and inputs to be changed at relatively low cost (Morawetz 1974; Steel 1977).

- Even when large-scale industries dominate, many SSEs retain a competitive advantage by serving dispersed local markets, providing differentiated products with low-scale economies for niche markets, or specializing as subcontractors for larger firms (Anderson 1982; Anheier and Seibel 1987).

Adjustment policies such as those pursued by Ghana can be hypothesized to open opportunities for SSEs to expand. By introducing greater competitive forces 
and opening up export opportunities, adjustment policies are intended to yield a more efficient, dynamic structure of production by forcing inefficient firms to lower production costs or die out. A substantial negative impact could be expected on inefficient large-scale firms that were created under heavy protection to import-intensive, import-substitution industries, which characterized much of Ghana's (and other African countries') industrial structure. However, this effect would be mitigated to the extent that firms could take advantage of increased availability of foreign exchange to utilize excess capacity.

SSEs could offset the negative effects of import liberalization to the extent that they could use local inputs to produce import substitutes or exports, thereby taking advantage of the incentives provided by a greatly devalued exchange rate. However, the ability of sses to grow would also depend on the ability of the financial system to shift resources to them from industries that are declining and on how severely demand and credit were restrained under stabilization policies.

\section{TRENDS BEFORE ADJUSTMENT}

As Ghana's economy declined in the late 1970 s and early 1980s, foreign exchange scarcities curtailed production in its large import-substitution industries, which depended heavily on imported inputs. Capacity utilization fell from 40 percent in 1978 to 21 percent in 1982. Although public policy prevented employment from falling in state-owned enterprises, large private firms recorded in the industrial statistics in Ghana reduced employment by a third during this period.

Through innovative use of local raw and waste materials, some technically astute small entrepreneurs were able to fill gaps left by declining imports and large-scale output by producing import substitutes such as soap, metal products, and vehicle spare parts (Anheier and Seibel 1987; Dawson 1990). However, many SSEs were constrained by lack of access to complementary imported inputs, such as chemicals for tie-dye, screws for carpenters, ink for printers, perfumes for cosmetics producers, and even yarn for weavers of traditional kente cloth. There is no conclusive evidence as to whether opportunities for SSES outweighed constraints during the period of economic decline and tight controls.

Stagnant income per capita in the 1960s stimulated growth in selfemployment as people attempted to maintain family incomes. Women accounted for 63 percent of the total increase in nonagricultural employment from 1960 to 1970 - half of them in manufacturing and 91 percent of them in enterprises of fewer than 10 workers (Steel 1981). This process accelerated with steeply declining real incomes in the late 1970 s and early 1980 s. Female participation in the formal labor force jumped from 64 percent in 1970 to 82 percent in 1984 , and women accounted for the entire increase in manufacturing employment during that period (Steel 1981; Ghana 1987). With rising inflation in the 1970 s and 1980s, many modern sector workers turned to self-employment ac- 
tivities to supplement their declining real wages, while others were forced to work on their own when they were laid off. As a residual source of employment and economic survival, the microenterprise sector is generally thought to have expanded in the face of a declining economy.

\section{ENTREPRENEURS DURING AdJUSTMENT}

The survey identified small enterprises as an important locus of investment under the adjustment program. Almost half of the firms with fewer than 30 workers were established after the 1983 reforms. In contrast, none of those with 30 or more workers was established after 1983 (including 31 respondents to a related survey of large-scale firms). Although it is not known what percentage of new firms would be "normal" for each size group, the difference in the proportion of new businesses between the small and large groups is striking.

Many new owners were highly entrepreneurial in that they saw a profitable opportunity and took it. None followed their parents into business, as against 38 percent of pre-1984 owners. Their primary motivation was to apply their training ( 43 percent versus 13 percent of pre-1984 owners). These new entrepreneurs were better educated than their predecessors, both formally and through significant past job experience. The number of new small firm owners who finished middle school was twice that of pre-1984 owners (60 percent versus 29 percent).

The most successful SSE entrepreneurs moved into profitable niches producing specialized, nontraditional items, such as freezers, water coolers, and drums, to compete with increasingly expensive imports. Some undertook innovative processing of locally available materials, such as fuel briquettes from sawdust and knives from used band-saw blades and metal packing strips. Some left large companies to start their own business. Most started small and moved up, some more quickly than others.

In contrast, new microentrepreneurs (with fewer than 4 workers) were more likely to have entered business through the apprenticeship route: 44 percent versus 25 percent of pre-1984 microentrepreneurs. Ghana's informal apprenticeship system ensures that existing skills are maintained in trades such as garments, carpentry, vehicle repair, and metal-working; however, this also ensures that the numbers of young adults with similar skills will increase, without necessarily imparting the entrepreneurial and innovative abilities needed to become more productive. For example, one seamstress compensated for declining demand by increasing her paying apprentices to 37 . With negligible orders for garments, the girls learned to sew on paper bags. The seamstress solved her immediate need for income but trained her future competition. The apprentices' futures probably will depend more on the growth of income among Ghana's workers than on their abilities as seamstresses.

Women owned 15 of the 82 firms surveyed; all but 2 of them had fewer than 10 workers and were found in food processing, textiles, and garments. These 
subsectors accounted for 78 percent of total female manufacturing employment in 1984 (Ghana 1987). Although female entrepreneurs generally were less educated than their male counterparts in the sample, among the microenterprises women tended to be better educated than men ( 43 percent with 12 or more years of schooling as against 28 percent of men) and to have been in business much longer (an average of 17 years). One interpretation is that many women may view successful self-employment as a satisfactory, permanent source of income rather than as a step toward expansion. Another is that women have limited opportunities to expand their enterprises because of other substantial demands on their time. The problems women face in business in Ghana appear to arise mostly from their concentration in easy-entry, highly competitive activities and from gender-related differences in education and family responsibilities.

\section{Employment, Output, AND InVestment Under Adjustment}

This section analyzes how adjustment affected employment, production, and investment at the firm level and pays particular attention to differences between firms established before and after the ERP was launched. The evidence indicated that adjustment policies shifted the advantage away from larger firms and that entry and growth were particularly high among sSEs.

\section{Changes in Employment}

Table 1 shows the average annual growth in employment by firm size during 1975-83 and 1983-89 for sample firms established by 1975. During 1975-83, incomes fell and import controls were tightened as foreign exchange became increasingly scarce. Nevertheless, employment grew at 7.6 percent a year in the medium- and large-scale firms in the sample, presumably because imports were channeled to these firms and because the government maintained strong pressure on both public and private sector firms not to lay off workers. Microen-

Table 1. Employment Growth, by Age and Size of Firm, 1975-83 and 1983-89

(weighted average annual percentage growth)

\begin{tabular}{|c|c|c|c|c|c|c|c|}
\hline \multirow[b]{3}{*}{ Firm size } & \multirow{2}{*}{\multicolumn{2}{|c|}{$\begin{array}{c}\text { Firms established } \\
\text { by } 1975\end{array}$}} & \multicolumn{2}{|c|}{ Growth since start } & \multirow{2}{*}{\multicolumn{3}{|c|}{$\begin{array}{c}\text { Number of firms } \\
\text { established by }\end{array}$}} \\
\hline & & & \multirow{2}{*}{$\begin{array}{c}\text { Established } \\
\text { by } 1983\end{array}$} & \multirow{2}{*}{$\begin{array}{c}\text { Established } \\
\text { during } \\
1984-89\end{array}$} & & & \\
\hline & $1975-83$ & $1983-89$ & & & 1975 & 1983 & 1989 \\
\hline 1-3 workers & 0.0 & 16.0 & 9.7 & 7.6 & 4 & 17 & 33 \\
\hline 4-9 workers & -0.2 & 6.2 & 1.3 & 45.1 & 7 & 16 & 26 \\
\hline $10-29$ workers & 0.5 & 3.1 & 8.1 & 19.1 & 9 & 9 & 16 \\
\hline $30+$ workers & 7.6 & -17.2 & 1.1 & n.a. & 5 & 7 & 7 \\
\hline
\end{tabular}

n.a. Not applicable.

Note: Size categories and weights are based on total employment in 1983 for firms established by then, to reveal the impact according to firm size at the beginning of adjustment. For firms established from 1984 to 1988 , size categories are based on 1989 employment and weights on employment at start-up.

Source: Survey data. 
terprises and SSEs, however, lacked government protection and suffered stagnant or declining employment as incomes and their access to inputs fell.

The preceding data are for individual firms in the sample. In the aggregate, as some firms shut down, production and employment were falling in the largescale (especially private) sector. Conversely, aggregate employment (although not necessarily production) in microenterprises and SSES is thought to have increased, as people sought alternative and supplementary sources of income.

The picture reversed sharply under the ERP from 1983 to 1989. Employment fell rapidly in the medium- and large-scale sample firms, partly because many were able to shed excess labor and partly because they were squeezed between high costs of imported inputs and greater competition from liberalized imports. Employment rose in all the other size categories, in part reflecting expansion as smaller firms gained greater access to inputs and rural demand recovered.

One striking feature of the recovery was that a much higher proportion of the firms surveyed reported an increase in employment ( 62 percent) than in production (39 percent; table 2). This was true for all size groups and most subsectors; employment growth lagged only in food products and soap and cosmetics. Increased labor absorption in part represents substitution in response to drastically eroded real wages and increased interest rates, making labor relatively cheap. A sharp increase in the number of microenterprises confirms that many workers turned to this sector for additional income (part-time workers accounted for 50 percent of microenterprise employment, as against an average of 13 percent for all firms surveyed).

Table 2. Production and Employment Trends, by Size of Firm, for Firms Established by 1983 and during 1984-89 (percentage of respondents in each category)

\begin{tabular}{|c|c|c|c|c|c|c|c|c|c|c|}
\hline \multirow[b]{2}{*}{ Impact } & \multirow{2}{*}{$\begin{array}{l}\text { All firms } \\
\text { surveyed }^{a}\end{array}$} & \multicolumn{4}{|c|}{$\begin{array}{c}\text { Number of workers } \\
\text { in firms established } \\
\text { by } 1983\end{array}$} & \multicolumn{4}{|c|}{$\begin{array}{c}\text { Number of workers } \\
\text { in firms established } \\
\text { during 1984-89 }\end{array}$} & \multirow{2}{*}{$\begin{array}{l}\text { Large } \\
\text { firm } \\
\text { survey }\end{array}$} \\
\hline & & $1-3$ & $4-9$ & $10-29$ & $30+$ & $1-3$ & $4-9$ & $10-29$ & $30+$ & \\
\hline \multicolumn{11}{|c|}{ Change in production } \\
\hline Increase & 39 & 29 & 31 & 33 & 43 & 34 & 70 & 43 & n.a. & 58 \\
\hline Decrease & 43 & 65 & 44 & 67 & 43 & 46 & 20 & 14 & n.a. & 29 \\
\hline \multicolumn{11}{|c|}{ Change in employment } \\
\hline Increase & 62 & 47 & 56 & 78 & 71 & 56 & 80 & 71 & n.a. & 35 \\
\hline Decrease & 16 & 18 & 25 & 11 & 29 & 6 & 0 & 29 & n.a. & 39 \\
\hline Number of firms & 82 & 17 & 16 & 9 & 7 & 16 & 10 & 7 & 0 & 31 \\
\hline
\end{tabular}

n.a. Not applicable.

Note: Size categories are based on employment at the time of the survey in 1989 . Compared with table 1 , the microenterprise category includes some unsuccessful firms that declined, and the largest category includes some successful firms that grew. Firms reporting no change are not shown; so figures may not add to 100 percent.

a. Excluding large-firm survey.

Source: Survey data. 


\section{Production and Competition}

Between 1983 and 1989, approximately the same proportion of firms in the total sample increased production ( 39 percent) as decreased ( 43 percent; table 2). A clear pattern emerges when firms are broken down by size and period of establishment. Firms established before the ERP had a relatively high propensity to decline under adjustment policies. In contrast, firms in all size groups established since 1983 were more likely to have increased their output than those already in existence. New firms with 4 to 29 workers (SSEs) had especially high ratios of growing to contracting firms. This growth in the newer firms may be partly attributable to the initial spurt that characterizes many SSEs in their first three years (Liedholm 1990), as well as to their choice of activities with high growth potential. Nevertheless, microenterprises with 1 to 3 workers were more likely to have decreased than increased output.

Among firms with fewer than 30 employees, three-quarters reported that other SSES were the primary source of competition. Although 61 percent claimed that competition had increased since 1983 , only 12 percent mentioned imports as a major source of that competition. The principal subsectors affected by import competition were metal products (21 percent of firms, mostly in agricultural machinery, which could be imported duty-free) and soap and cosmetics (29 percent of the subsector, especially cosmetics firms that did little more than repackage imported materials).

\section{Investment}

Contrary to some observers' perceptions, investment was taking place, at least among small firms. Nearly half of the microenterprises sampled were established since 1983 (high birth and death rates are expected in this group); while 38 and 44 percent of firms with 4 to 9 and 10 to 29 workers, respectively, entered since 1983. As import costs rose, many of these new firms sprang up to supply lowcost substitutes, particularly from local materials. Examples included pottery, locally mixed paints, and simple agricultural implements. In addition, about half of the firms established by 1983 had purchased some new equipment by 1989 (table 3).

\section{Adaptations}

Many firms adapted to new price incentives by altering their product linesan important motivation for replacing outmoded equipment that had deteriorated during the late $1970 \mathrm{~s}$ and early $1980 \mathrm{~s}$. The product mix was altered during the ERP by 34 percent of all firms surveyed and generally by higher proportions for those established by 1983 (table 3). As the construction industry picked up, for example, metal workers began producing metal gates and burglar alarm systems. Unable to compete with imports, a chalk producer shifted to producing starch for the textile industry. Changes in product mix were especially 
Table 3. Production and Input Changes under Adjustment, by Size of Firm, for Firms Established by 1983, 1983-89

(percentage of respondents in each category)

\begin{tabular}{lccccc}
\hline & & \multicolumn{4}{c}{$\begin{array}{c}\text { Number of workers in firms } \\
\text { established by 1983 }\end{array}$} \\
\cline { 3 - 6 } Change & $\begin{array}{c}\text { All firms } \\
\text { surveyed }\end{array}$ & $1-3$ & $4-9$ & $10-29$ & $30+$ \\
\hline Bought new equipment & 49 & 43 & 56 & 56 & 57 \\
Product mix changed & $34^{\mathrm{b}}$ & 40 & 27 & 63 & $45^{\mathrm{b}}$ \\
Selling in different markets & 15 & 12 & 19 & 0 & 43 \\
Have exported (directly or indirectly) & 9 & 6 & 8 & 7 & 14 \\
Have considered exporting & 38 & 28 & 46 & 44 & 43 \\
Imported share of raw materials & & & & & \\
$\quad$ Actual percentage share & $34.0^{\mathrm{b}}$ & 19.1 & 19.1 & 62.8 & $52.6^{\mathrm{b}}$ \\
$\quad$ Change since 1983 & & & & & \\
$\quad$ Greater & $98^{\mathrm{b}}$ & 11 & 11 & 25 & $8^{\mathrm{b}}$ \\
$\quad$ Smaller & 22 & 11 & 13 & $83^{\mathrm{b}}$ \\
Easier to get & $73^{\mathrm{b}}$ & 89 & 64 & 50 & $88^{\mathrm{b}}$ \\
$\quad$ Imported inputs & $57^{\mathrm{b}}$ & 64 & 44 & 17 & $67^{\mathrm{b}}$ \\
$\quad$ Domestic inputs & & & & & \\
Harder to get or too costly & $12^{\mathrm{b}}$ & 0 & 18 & 33 & $0^{\mathrm{b}}$ \\
$\quad$ Imported inputs & $20^{\mathrm{b}}$ & 21 & 25 & 33 & $0^{\mathrm{b}}$ \\
$\quad$ Domestic inputs & 82 & 17 & 16 & 9 & 7 \\
Number of firms & & & & & \\
\hline
\end{tabular}

a. Includes firms established after 1983 as well as before.

b. Includes an additional 24 firms from a separate survey of large-scale enterprises.

Source: Survey data.

prevalent in the soap and cosmetics and the textiles and garments subsectors ( 83 and 50 percent of firms, respectively). Those manufacturing food, wood, and metal products had less need to change because their dependence on imported inputs was low $(19,10$, and 18 percent, respectively) and their products were adapted to local tastes, making them less vulnerable to competition from standardized imports.

Along with changes in product mix, a number of firms shifted their marketing strategies. Large firms in particular had to seek out new domestic markets (43 percent; table 3). Devaluation raised the price of exports, and the response was especially high in the timber industry. New, small sawmills were buying logs from those with timber concessions and sawing them into lumber for larger exporting firms. Of the total sample, 38 percent were interested in exporting, even though only 9 percent had any direct or indirect experience with exports. SSE exports tended to be somewhat haphazard and on a small scale. For example, a tie-dye producer sold a relatively small volume of her fabric to a German buyer, and a producer of commercial freezers sold several units to traders from Nigeria and Mali.

\section{Use of Inputs}

The use of imported inputs was affected in two opposite ways by Ghana's adjustment policies. First, import liberalization made imports more available to 
small firms, previously excluded by the large-scale firms that were favored by the import licensing system. Second, devaluation raised the cost of imported inputs, favoring industries with high proportions of domestic inputs and value added. Among firms in the sample, the same proportion used imported inputs exclusively as used only domestic raw materials ( 22 percent). On the average, the proportion of imported raw materials used by firms with fewer than 10 workers ( 19 percent) was about a third that used by larger ones, making them less vulnerable to devaluation (table 3 ). While the majority of respondents of all sizes reported that imports had become easier to obtain, only for those with 10 to 29 workers did increased access outweigh the substitution effect: twice as many ( 25 percent) increased their import content as decreased (13 percent). None of the firms in wood, metal products, and textiles and garments reported any change in import content (partly because import shares were already relatively low).

The overwhelming majority of firms with 30 or more workers reported substitution of domestic for imported inputs under the ERP ( 83 percent, in contrast to an average of only 16 percent of firms with fewer than 30 workers; table 3), although no significant change in average import content appears in recorded statistics for large-scale industry from 1984 to 1988 . One reason for the relatively low substitution found among smaller firms was that relative prices may not have changed much in favor of domestic materials, most of which are tradable. A much larger share of sses cited the high price of local raw materials as a problem than that of imported inputs (for which they previously had to pay black market prices). The price of agricultural raw materials had risen because food prices were liberalized. The price of cloth to the tie-dye and garment subsector remained high because extra tariff protection was provided to large textile mills, and costs in the greycloth factory were not significantly reduced. Since timber is exportable, its domestic price tended to rise pari passu with devaluation. Good scrap metal became increasingly scarce. Thus there may have been supply-side constraints to rapid expansion of some sses that were based on local raw materials.

\section{Constraints on Adjustment and Growth}

Although some firms found market niches with good growth potential, many were not able to pass on fully the increased costs of raw materials and equipment to consumers in the form of higher prices because of weak demand and an inflow of competing imports. Most firms experienced a financial squeeze, including those on sound financial footing in the past. The survey revealed that if demand were eliminated as a problem, finance would be an even more severe constraint on growth. In sum, the incentive side of the adjustment process was working-less efficient firms were being squeezed-but the financial side was not functioning adequately to enable more efficient firms to grow.

Respondents to the survey identified lack of access to credit (especially for 
working capital), demand, and increased cost of inputs as their principal operating problems, but the relative importance varied by size. The importance of credit increased with firm size, while demand problems were most evident among microenterprises. SsEs were more concerned about the high price of local inputs, whereas larger firms placed more emphasis on imported input costs. ssEs also were most eager to replace old equipment and hence were most affected by lack of access to term lending.

The majority of sses ( 58 to 64 percent of firms with 4 to 29 workers) saw their ability to respond to market incentives as constrained primarily by lack of access to institutional credit for working capital and for equipment (table 4). The other two main constraints-the high cost of local materials and the need to replace old equipment-indicated why credit was needed to facilitate their supply re-

Table 4. Constraints by Size of Firm, 1983-89 (percentage of respondents in each category)

\begin{tabular}{|c|c|c|c|c|c|}
\hline \multirow[b]{2}{*}{ Constraint } & \multirow{2}{*}{$\begin{array}{l}\text { All firms } \\
\text { surveyed }\end{array}$} & \multicolumn{4}{|c|}{ Number of workers } \\
\hline & & $1-3$ & $4-9$ & $10-29$ & $30+$ \\
\hline \multicolumn{6}{|l|}{ Main constraint on sales } \\
\hline \multicolumn{6}{|l|}{ Demand } \\
\hline $\begin{array}{l}\text { Can sell current production but } \\
\text { no more } \\
\text { Can't sell current production }\end{array}$ & $\begin{array}{l}24 \\
24\end{array}$ & $\begin{array}{l}19 \\
38\end{array}$ & $\begin{array}{l}23 \\
19\end{array}$ & $\begin{array}{l}21 \\
14\end{array}$ & $\begin{array}{r}57 \\
0\end{array}$ \\
\hline \multicolumn{5}{|l|}{ Bank loan } & 100 \\
\hline $\begin{array}{l}\text { Have ever had one } \\
\text { Have tried to get one in past } 5\end{array}$ & 32 & 18 & 19 & 60 & 86 \\
\hline years & 47 & 28 & 48 & 73 & 71 \\
\hline & \multicolumn{4}{|c|}{ Major competition from } & 71 \\
\hline $\begin{array}{l}\text { Imports } \\
\text { Small firms }\end{array}$ & $\begin{array}{l}21^{a} \\
65^{a}\end{array}$ & $\begin{array}{l}13 \\
75\end{array}$ & $\begin{array}{r}8 \\
72\end{array}$ & $\begin{array}{r}7 \\
72\end{array}$ & $\begin{array}{l}50^{\mathrm{a}} \\
37^{\mathrm{a}}\end{array}$ \\
\hline \multicolumn{6}{|l|}{ Top four operating problems ${ }^{b}$} \\
\hline $\begin{array}{l}\text { For raw materials } \\
\text { To buy equipment }\end{array}$ & $\begin{array}{l}57 \\
29\end{array}$ & $\begin{array}{l}55 \\
18\end{array}$ & $\begin{array}{l}54 \\
35\end{array}$ & $\begin{array}{l}63 \\
50\end{array}$ & $\begin{array}{l}71 \\
14\end{array}$ \\
\hline \multicolumn{6}{|l|}{ Demand } \\
\hline Consumers lack of money & 35 & 55 & 23 & 19 & 29 \\
\hline Too many other firms & 17 & 21 & 12 & 25 & 0 \\
\hline Can't afford my product & 11 & 15 & 12 & 6 & 0 \\
\hline \multicolumn{6}{|l|}{ Inputs } \\
\hline Local material prices & 22 & 30 & 23 & 69 & 14 \\
\hline Imported input prices & 18 & 9 & 23 & 25 & 29 \\
\hline Can't get local materials & 11 & 15 & 15 & 0 & 0 \\
\hline \multicolumn{6}{|l|}{ Equipment } \\
\hline Needs replacing & 23 & 12 & 35 & 31 & 14 \\
\hline Number of firms & 82 & 33 & 26 & 16 & 7 \\
\hline
\end{tabular}

a. Includes an additional 24 firms from a separate survey of large-scale enterprises.

b. Firms could list up to four problems, so the percentages can add to more than 100 percent. Problems listed by less than 11 percent of firms are not shown.

Source: Survey data. 
sponse. Many of these firms had orders for their products but insufficient working capital to meet them, due in part to slim profit margins and delays in collecting from customers. Because responses were based on owners' perceptions, internal management problems were likely to be underrepresented as constraints. Nevertheless, almost all the owners of firms with fewer than 10 workers expressed a desire to improve their business skills, particularly those relating to technology and accounting.

Microenterprises were much more likely to be constrained by demand: 38 percent could not even sell their current production (table 4). They attributed weak demand primarily to people's lack of money-reflecting decreased real income per capita since the 1970 s as well as restrained demand under the ERP. Increased competition from other small firms was also a factor: a growing number of competitors were slicing up a diminished pie. Thus the fortunes of the smallest firms depend most on growth of demand among low-income consumers (rural and urban), who are their principal markets.

In contrast to firms with fewer than 30 workers, larger firms saw imports as their main competition, and none cited competition from other domestic firms among their top four problems. Although they did not feel as immediately constrained by demand as microenterprises, 57 percent thought that demand could not absorb further increases in their production (table 4). These results confirm the importance of import liberalization to force large firms to act competitively.

\section{Credit}

As could be expected under tight monetary policies that curtail government spending and restrain credit, almost all of the survey respondents agreed that credit had become harder to get under the ERP (table 4). The survey also indicated significantly less access to bank loans for firms with fewer than 10 workers (fewer than 20 percent had ever had a loan) than for those with 10 to 29 and more than 30 workers (60 and 86 percent, respectively). More than 70 percent of firms with 10 or more workers had applied for a loan since the ERP began, thus indicating a high demand for credit. Only 9 percent of firms said they would refuse a loan for working capital at 30 percent interest, and only 25 percent (mainly microenterprises) would decline credit for investment purposes. Microenterprises often demurred because they doubted that they could sell enough to repay their loans.

\section{Regulatory Environment}

Given the severity of finance and demand problems, the regulatory environment was rarely mentioned among the top four problems, except for taxes (cited by 14 percent of all respondents and 30 percent of large-scale firms). Infrastructure (especially electricity interruptions) and transportation costs were cited by 5 to 7 percent. Only 5 percent mentioned the business environment generally, and just 3 percent (large-scale firms only) listed regulations or licensing as a problem. 
Regulatory problems appeared to affect larger firms more than smaller ones, and exporters more than those producing for the domestic market. Location was the only significant regulatory concern of firms with fewer than 10 workers, many of whom had been affected by relocation and demolition efforts by urban authorities.

Nevertheless, the business environment may be more of a concern for new investors than for existing producers who have already adapted to it. Uncertainty about the economy was seen as a restraint on new investment by 38 percent of respondents, especially those with 10 or more workers. More than a third of large firms also expressed some reservations about the government's attitude toward private investment.

\section{ConClusions}

Structural adjustment policies have begun altering the structure of industrial production in Ghana. Changes in the exchange rate, trade policy, and price controls have had different effects on incentives and profits. Although both positive and negative effects were found within each size and subsector group, differences between group averages indicate that structural changes were occurring. Large firms were particularly affected by competition from liberalized imports, and the increased cost of imported inputs forced many to increase the content of local raw material. Small enterprises were especially responsive in adapting their product lines to changing market opportunities and in taking advantage of increased access to imported inputs. Many entrepreneurs sought new products, techniques, and markets, and others would do so if they had greater access to resources, especially finance. New small enterprises were generally performing well.

Nevertheless, the scarcity of credit and the absence of mechanisms to shift resources from declining firms to those with greater growth potential appeared to restrain investment to take advantage of new opportunities. SSES were quick to identify lack of credit for raw materials and equipment as major constraints to expansion, and they expressed strong interest in loans at current interest rates. Increased access to credit would greatly facilitate SSEs' contributions to recovery and adjustment of the industrial sector.

In contrast, microenterprises were much more likely to view weak demand as a major constraint-a consequence of the sharp fall in income per capita in the decade before the ERP and of restraints on demand under the ERP. Employment in microenterprises (including self-employment) mushroomed as formal sector employment and incomes diminished, but much of this growth was driven by excess supply of labor rather than by production-generating demand. Income and productivity may decline further without increased demand for the type of goods and services produced by this already overcrowded, low-wage sector. Policies that put more money into the hands of the low-income population (for example, through improving the terms of trade for farmers) are likely to have 
greater effect on microentrepreneurs' earnings than supply-side measures to assist individuals.

As demand and credit problems are resolved, taxation and the business climate may come increasingly into play as constraints on investment, at least for larger firms; smaller firms tend to be less concerned with regulations. Economic and political stability and a positive attitude toward private profit would help reduce uncertainty-an important consideration for new investors. The cost of doing business could be reduced through lower, more transparent taxation. Export procedures, as well as financing, need improvement for SSEs to live up to their export potential. In addition to such measures, a long-run strategy should include complementary education and technical training to enhance the ability of Ghana's small entrepreneurs to contribute to industrial development.

\section{REFERENCES}

The word "processed" describes informally reproduced works that may not be commonly available through libraries.

Anderson, Dennis. 1982. "Small Industry in Developing Countries: A Discussion of Issues." World Development $10(11$, November $): 913-48$.

Anheier, Helmut K., and Hans Dieter Seibel. 1987. Small-Scale Industries and Economic Development in Ghana: Business Behaviour and Strategies in Informal Sector Economies. Cologne Development Studies 3. Saarbrucken, Germany: Breitenbach.

Bolton Committee. 1971. Bolton Committee Report: Small Firms. Cmnd. 4811. London: Her Majesty's Stationery Office. Quoted in Ian M. D. Little and others, 1987. Small Manufacturing Enterprises. New York: Oxford University Press.

Bruton, Henry. 1990. "Broad-Based Growth." Paper presented at a workshop on Research Priorities for Policy Reforms Supporting Broad-Based Growth and Democracy. USAID/APRE/SMIE. Washington, D.C. Processed.

Cortes, Mariluz, Albert Berry, and Ashfaq Ishaq. 1987. Success in Small-and MediumScale Enterprises: The Evidence from Colombia. New York: Oxford University Press.

Dawson, Jonathan. 1990. "The Wider Context: The Importance of the Macroenvironment for Small Enterprise Development." Small Enterprise Development 1 (3, September):39-46.

Ghana, Republic of. 1987. 1984 Population Census of Ghana: Demographic and Economic Characteristics, Total Country. Accra: Ghana Statistical Service.

1989. Ghana National Industrial Census 1987. Accra: Ghana Statistical Service.

Kilby, Peter. 1988. "Breaking the Entrepreneurial Bottleneck in Late-Developing Countries: Is There a Useful Role for Government?" Journal of Development Planning 18:221-49.

Liedholm, Carl. 1990. The Dynamics of Small-Scale Industry in Africa and the Role of Policy. GEMINI Working Paper 2. Washington, D.C.: USAID.

Liedholm, Carl, and Don Mead. 1987. "Small-Scale Industries in Developing Countries: Empirical Evidence and Policy Implications." International Development Paper 9. Michigan State University, Department of Agricultural Economics, East Lansing. Processed. 
Little, Ian M. D., Dipak Mazumdar, and John M. Page, Jr. 1987. Small Manufacturing Enterprises: A Comparative Analysis of India and Other Economies. New York: Oxford University Press.

Morawetz, David. 1974. "Employment Implications of Industrialization in Developing Countries: A Survey." Economic Journal 84 (335, September):491-542.

Nanjundan, S. 1987. "Small and Medium Enterprises: Some Basic Development Issues." Industry and Development 20:1-50.

Schmitz, Hubert. 1982. "Growth Constraints on Small-Scale Manufacturing in Develop- . ing Countries: A Critical Review." World Development 10 (6, June):429-50.

Staley, Eugene, and Richard Morse. 1965. Modern Small Industry for Developing Countries. New York: McGraw-Hill.

Steel, William F. 1977. Small-Scale Employment and Production in Developing Countries: Evidence from Ghana. New York: Praeger.

- 1981. "Female and Small-Scale Employment under Modernization in Ghana." Economic Development and Cultural Change 30 (1, October):153-67.

Steel, William F., and Yasuoki Takagi. 1983. "Small Enterprise Development and the Employment-Output Trade-Off." Oxford Economic Papers 35:423-46.

UNiDo. 1989. "Environment Conducive to Sustained Growth of Small- and MediumScale Enterprises." Discussion Paper ID/WG.492/4 for the First Consultation on Small- and Medium-Scale Enterprises including Co-operatives (Bari, Italy), Vienna. Processed. 